\title{
KEBUTUHAN FASILITAS PENYEBERANGAN JALAN DI PUSAT PERBELANJAAN MODERN (STUDI KASUS: MALL OF SERANG)
}

\section{Andi Maddepunggeng1, Dwi Esti Intari² dan Nur Ajeng Apdiana ${ }^{3}$}

1Prodi Teknik Sipil, Universitas Sultan Ageng Tirtayasa, Jl. Jenderal Sudirman Km 3 Cilegon, Banten, 42435

Email korespondensi: andi.made@yahoo.com

2 Prodi Teknik Sipil, Universitas Sultan Ageng Tirtayasa, Jl. Jenderal Sudirman Km 3 Cilegon, Banten, 42435

Email: dwiesti@untirta.ac.id

3 Prodi Teknik Sipil, Universitas Sultan Ageng Tirtayasa, Jl. Jenderal Sudirman Km 3 Cilegon, Banten, 42435

Email: ajengapdiana3@gmail.com

\begin{abstract}
ABSTRAK
Kota Serang merupakan pusat pemerintahan Provinsi Banten. Mall Of Serang merupakan salah satu pusat perbelanjaan modern di Kota Serang, yang terletak di Jalan Raya Jakarta yang lokasinya sangat strategis karna dekat dengan gerbang tol Serang Timur. Penelitian ini bertujuan untuk mengetahui fasilitas penyeberangan yang layak dan untuk mengetahui desain fasilitas penyeberangan jalan di depan Mall of Serang. Menganalisa kebutuhan fasilitas penyeberangan jalan ini menggunakan panduan dari Kementerian Pekerjaan Umum Dan Perumahan Rakyat Tahun 2018. Perencanaan Teknis Fasilitas Pejalan Kaki dengan menggunakan rumus $\mathrm{PV}^{2}$ dimana $\mathrm{P}$ merupakan volume penyeberangan jalan (orang-jam) dan $\mathrm{V}$ merupakan volume arus kendaraan (kendaraan/jam) dan untuk mendesain fasilitas penyeberangan jalan menggunakan software google sketchup 2021. Hasil dari penelitian ini bahwa volume lalu lintas kendaraan dan volume penyeberang jalan dalam rumus $\mathrm{PV}^{2}$ menghasilkan $\mathrm{PV}^{2}$ rata-rata dengan $\mathrm{P}=59$ orang/jam, $\mathrm{V}=12597$ (kendaraan/jam), maka menghasilkan $\mathrm{PV}^{2}=9303698748\left(9 \times 10^{9}\right)$ dan hasil tersebut disesuaikan kedalam tabel penentuan fasilitas penyeberangan pejalan kaki menurut Kementerian Pekerjaan Umum Dan Perumahan Rakyat Tahun 2018 yang menghasilkan fasilitas berupa pelican cross dengan kriteria $\mathrm{P}=50-1100$ orang/jam dan $\mathrm{V}=>750$ kendaraan/jam.
\end{abstract}

Kata kunci: Pejalan Kaki, Fasilitas Penyeberangan Jalan, Pelican Cross

\begin{abstract}
Serang City is the administrative center of Banten Province. Mall Of Serang is one of the modern shopping centers in Serang City, which is located on Jalan Raya Jakarta which is very strategically located because it is close to the Serang Timur toll gate. This study aims to determine the proper crossing facilities and to determine the design of the crossing facilities in front of the Mall of Serang. Research at the Mall of Serang shopping center which aims to determine proper crossing facilities and to determine the design of crossing facilities in front of Mall of Serang. Analyzing the need for road crossing facilities using guidelines from the Ministry of Public Works and Public Housing in 2018 concerning Technical Planning for Pedestrian Facilities using the PV2 formula where $P$ is the volume of crossing roads (person/hour) and $V$ is the volume of vehicle flow (vehicles/hour) and to design a road crossing facility using the Google SketchUp 2021 software. The results of this study that the volume of vehicle traffic and the volume of pedestrians in the formula PV2 produces an average PV2 with $P=59$ people/hour, $V=12597$ (vehicles/hour), then produces PV2 = 9303698748 (9×109) and the results This is adjusted into the table for determining pedestrian crossing facilities according to the Ministry of Public Works and Public Housing in 2018 which produces facilities in the form of a pelican cross with criteria $P=50-1100$ people/hour and $V=>750$ vehicles/hour.
\end{abstract}

Keywords: Pedestrians, Crossing Facilities, Pelican Cross 


\section{PENDAHULUAN}

Kota Serang merupakan pusat pemerintahan Provinsi Banten. Letak Kota Serang yang strategis menjadikannya sebagai jalur utama penghubung lintas Jawa-Sumatera. Kota Serang memiliki luas wilayah 266,74 $\mathrm{km}^{2}$ dengan jumlah penduduk 688,603 jiwa (BPS Kota Serang, 2019).

Kota Serang merupakan Pusat Pemerintahan, pusat perdagangan dan pusat kebudayaan, dimana didalamnya terdapat banyak kegiatan seperti pendidikan, perbelanjaan, perdagangan, tempat peribadatan, terminal dan jasa lainnya.

Mall of Serang merupakan salah satu pusat perbelanjaan modern di Kota Serang dimana didalamnya terdapat toko-toko kecil, rumah makan dan tempat untuk berekreasi. Mall of Serang terletak di Jalan Raya Jakarta yang lokasinya sangat strategis karna dekat dengan gerbang Tol Serang Timur dan rumah sakit.

Lokasinya yang sangat strategis, sulit bagi pejalan kaki untuk menyeberang ataupun berjalan didaerah padat lalu lintas karena selama 24 jam berbagai jenis kendaraan selalu melintas di Jalan Raya Jakarta ini. Pejalan kaki di lokasi tersebut sebagian besar adalah pengunjung mall dan para karyawan.

Berdasarkan uraian diatas dapat disimpulkan bahwa pengadaan fasilitas penyeberangan jalan sangat penting dilakukan agar kenyamanan dan keamanan tercipta tanpa harus menimbulkan gangguan atau konflik pergerakan arus lalu lintas yang terjadi. Maka penulis melakukan analisis Kebutuhan Fasilitas Penyeberangan Jalan di Pusat Perbelanjaan Modern (Studi Kasus : Mall Of Serang).

\section{LANDASAN TEORI}

\section{Fasilitas pejalan kaki}

Fasilitas pejalan kaki didefinisikan semua bangunan yang disediakan untuk pejalan kaki guna memberikan pelayanan kepada pejalan kaki sehingga dapat meningkatkan kelancaran, keamanan dan kenyamanan pejalan kaki. (Tata Cara Perencanaan Fasilitas Pejalan Kaki Di Kawasan Perkotaan, 1995).

Fasilitas pejalan kaki terdiri dari beberapa jenis sebagai berikut:

1. Jalur pejalan kaki (trotoar)

2. Penyeberangan Sebidang:
a. Zebra cross
b. Pelican cross

3. Penyeberangan tidak sebidang:

a. Jembatan penyeberangan

b. Terowongan

\section{Fasilitas penyeberangan}

Fasilitas penyeberangan didefinisikan fasilitas pejalan kaki untuk penyeberang jalan. (perekayasaan fasilitas pejalan kaki di wilayah kota, 1997). Untuk menganalisa kebutuhan fasilitas penyeberangan jalan perlu dipelajari karakteristik serta perilaku pejalan kaki yang menyeberang jalan. Adapun karakteristik pejalan kaki tersebut adalah:

1. Kecepatan menyeberang

Kecepatan menyeberang adalah jarak dibagi waktu. Kecepatan berjalan dipengaruhi oleh faktor-faktor volume pejalan kaki, usia oejlan kaki, jenis kelamin pejalan kaki, tingkat kesehatan fiskk pejalan kaki, kepadatan pejalan kaki dari arah berlawanan, kemiringan jalan, lebar penyeberang, jarak terhadap kendaraan yang datang, kecepatan kendaraan yang datang dan cuaca.

2. Volume

Volume pejalan kaki adalah jumlah pejalan kaki yang melewati titik tertentu setiap satuan waktu. Volume pejalan kaki dinyatakan dalam pejalan kaki/meter/detik atau pejalan kaki/meter/menit. 


\section{Perencanaan fasilitas penyeberangan}

Kriteria yang dapat digunakan dalam memilih fasilitas penyeberangan sebidang didasarkan pada formula empiris dimana:

$$
\text { P. } V^{2}
$$

Dengan $\mathrm{P}=$ arus pejalan kaki yang menyeberang di arus jalan sepanjang 100 meter setiap jam nya (pejalan kaki/jam), V = arus lalu lintas kendaraan setiap jam (kend/jam).

Nilai $\mathrm{P}$ dan $\mathrm{V}$ diatas merupakan arus ratarata pejalan kaki dan kendaraan pada jam sibuk. Dari nilai $\mathrm{PV}^{2}$ direkomendasikan pemilihan jenis fasilitas penyeberangan seperti di sajikan pada Tabel 1 dan Tabel 2

Tabel 1. Pemilihan Fasilitas Penyeberangan Sebidang

\begin{tabular}{llll}
\hline \multicolumn{1}{c}{$\boldsymbol{V V}^{\boldsymbol{2}}$} & \multicolumn{1}{c}{$\boldsymbol{P}$} & $\boldsymbol{V}$ & \multicolumn{1}{c}{$\begin{array}{c}\text { Rekomendasi } \\
\text { Awal }\end{array}$} \\
\hline$>10^{8}$ & $\begin{array}{l}50- \\
1100\end{array}$ & $\begin{array}{l}300- \\
500\end{array}$ & Zebra Cross \\
\hline$>2 \times$ & $50-$ & $400-$ & $\begin{array}{l}\text { Zc dengan } \\
\text { Pelindung }\end{array}$ \\
\hline $10^{8}$ & 1100 & 750 & Pelican \\
\hline$>10^{8}$ & $50-$ & $>500$ & \\
& 1100 & & \\
\cline { 2 - 3 } & $>1100$ & $>300$ & \\
\hline$>2 \times$ & $50-$ & $>750$ & Pelican dengan \\
$10^{8}$ & 1100 & & lapak tunggu \\
\cline { 2 - 3 } & $>1100$ & $>400$ & \\
\hline
\end{tabular}

Sumber: Perencanaan teknis pejalan kaki, 2018

\section{Penyeberangan tidak sebidang}

Kriteria yang dapat digunakan dalam memilih fasilitas penyeberangan tidak sebidang:

a. Pada fasilitas penyeberangan sebidang sudah mengganggu arus lalu lintas yang ada;

b. Frekuensi kecelakaan yang melibatkan pejalan kaki sudah cukup tinggi;

c. Pada ruas jalan dengan kecepatan rencana $70 \mathrm{~km} / \mathrm{jam}$;

d. Pada kawasan strategis, tetapi tidak memungkinkan para penyeberang jalan untuk menyeberang jalan selain pada penyeberangan tidak sebidang.

Beberapa ketentuan yang harus diperhatikan dalam perencanaan fasilitas penyeberangan tidak sebidang:

a. Penyeberangan tidak sebidang harus dapat diakses dengan mudah oleh penyandang cacat, misal dengan penambahan ram (pelandaian) atau dengan elevator.

b. Fasilitas penyeberangan tersebut harus dilengkapi dengan pencahayaan yang baik yang dapat meningkatkan keamanan bagi para pejalan kaki.

Lokasi dan bangunan harus memperhatikan nilai estetika serta kebutuhan pejalan kaki.

Tabel 2. Pemilihan Fasilitas Penyeberangan Tidak Sebidang

\begin{tabular}{ccccc}
\hline $\boldsymbol{V}^{\mathbf{2}}$ & $\boldsymbol{P}$ & $\boldsymbol{V}$ & $\begin{array}{c}\text { Rekomendasi } \\
\text { Awal }\end{array}$ \\
\hline$>2$ & $\mathrm{x}$ & $>1100$ & $>750$ & $\begin{array}{l}\text { Penyeberangan } \\
\text { tidak sebidang }\end{array}$ \\
\hline $10^{8}$ & & & \\
\hline
\end{tabular}

Sumber: Perencanaan teknis pejalan kaki, 2018

\section{METODE PENELITIAN}

Penelitian ini menganalisa kebutuhan fasilitas penyeberangan sesuai pedoman perencanaan fasilitas penyeberangan di perkotaan dari Bina Marga. Metode Penelitian ini bersifat observasi dilapangan dengan Teknik Survey lalu lintas untuk mengetahui jumlah volume lalulintas dan volume penyeberang. Lokasi penelitian dilakukan di depan Mall of Serang yang letaknya berada di Jalan Akses Tol Serang Timur, Kota Serang Banten.

\section{HASIL DAN PEMBAHASAN}

Untuk mendapatkan data volume kendaraan dan penyeberang di lokasi penelitian, maka dilakukan survey pendahuluan terlebih dahulu selama 2 hari pada hari weekday dan weekend untuk mengetahui jam-jam sibuk dilokasi penelitian. Survey dilakukan 2 hari dipintu masuk dan 2 hari dipintu keluar Mall 
of Serang, pada hari Jumat dan Sabtu selama 12 jam pada pukul 06.00-18.00.

Dari hasil survey pendahuluan dapat disimpulkan bahwa volume kendaraan dan volume penyeberang lebih besar dipintu keluar Mall of Serang dibandingkan di pintu masuk Mall of Serang dan 4 jam terbanyak untuk volume kendaraan dan volume penyeberang diambil pada pukul 07.0008.00, 12.00-14.00 dan 17.00-18.00.

\section{Analisis arus kendaraan}

Dalam penelitian ini dihitung pada waktu interval 15 menit, waktu survey yang dilakukan yaitu pada pukul 07.00-08.00, $12.00-14.00,17.00-18.00$ pada hari jum'at, sabtu, minggu. Tipe kendaraan yang diambil yaitu kendaraan ringan (KR), kendaraan sedang (KS), sepeda motor (SM), dan kendaraan tak bermotor (KTB).

Tabel 3. Data Volume Kendaraan

\begin{tabular}{|c|c|c|c|c|c|c|}
\hline \multicolumn{2}{|c|}{ Waktu } & $K R$ & $K S$ & $S M$ & $\begin{array}{c}K T \\
B\end{array}$ & $\begin{array}{c}\text { Tota } \\
I\end{array}$ \\
\hline \multirow{4}{*}{$\begin{array}{c}\text { Juma } \\
\text { t, 18- } \\
12- \\
2020\end{array}$} & $\begin{array}{l}07.00 \\
- \\
08.00\end{array}$ & 863 & 42 & 976 & 4 & 1885 \\
\hline & $\begin{array}{l}12.00 \\
- \\
13.00\end{array}$ & 872 & 80 & $\begin{array}{l}116 \\
3\end{array}$ & 6 & 2121 \\
\hline & $\begin{array}{l}13.00 \\
- \\
14.00\end{array}$ & $\begin{array}{l}122 \\
0\end{array}$ & $\begin{array}{l}18 \\
5\end{array}$ & $\begin{array}{l}170 \\
6\end{array}$ & 4 & 3115 \\
\hline & $\begin{array}{l}17.00 \\
- \\
18.00\end{array}$ & $\begin{array}{l}172 \\
7\end{array}$ & $\begin{array}{l}18 \\
8\end{array}$ & $\begin{array}{l}191 \\
2\end{array}$ & 8 & 3835 \\
\hline \multirow{4}{*}{$\begin{array}{c}\text { Sabtu } \\
\text { 19- } \\
12- \\
2020\end{array}$} & $\begin{array}{l}07.00 \\
- \\
08.00\end{array}$ & 954 & 40 & $\begin{array}{l}119 \\
8\end{array}$ & 8 & 2200 \\
\hline & $\begin{array}{l}12.00 \\
- \\
13.00\end{array}$ & $\begin{array}{l}105 \\
0\end{array}$ & 78 & $\begin{array}{l}124 \\
2\end{array}$ & 11 & 2381 \\
\hline & $\begin{array}{l}13.00 \\
- \\
14.00\end{array}$ & $\begin{array}{l}147 \\
4\end{array}$ & 82 & $\begin{array}{l}144 \\
3\end{array}$ & 7 & 3006 \\
\hline & $\begin{array}{l}17.00 \\
- \\
18.00\end{array}$ & $\begin{array}{l}152 \\
8\end{array}$ & 69 & $\begin{array}{l}202 \\
1\end{array}$ & 7 & 3625 \\
\hline
\end{tabular}

\begin{tabular}{|c|c|c|c|c|c|c|}
\hline \multicolumn{2}{|c|}{ Waktu } & $K R$ & $K S$ & $S M$ & $\begin{array}{c}K T \\
B\end{array}$ & $\begin{array}{c}\text { Tota } \\
l\end{array}$ \\
\hline \multirow{4}{*}{$\begin{array}{c}\text { Ming } \\
\text { gu, } \\
20- \\
12- \\
2020\end{array}$} & $\begin{array}{l}07.00 \\
- \\
08.00\end{array}$ & $\begin{array}{l}116 \\
9\end{array}$ & 90 & $\begin{array}{l}146 \\
6\end{array}$ & 2 & 2727 \\
\hline & $\begin{array}{l}12.00 \\
- \\
13.00\end{array}$ & $\begin{array}{l}184 \\
4\end{array}$ & $\begin{array}{l}11 \\
8\end{array}$ & $\begin{array}{l}205 \\
6\end{array}$ & 7 & 4025 \\
\hline & $\begin{array}{l}13.00 \\
- \\
14.00\end{array}$ & $\begin{array}{l}213 \\
8\end{array}$ & $\begin{array}{l}12 \\
6\end{array}$ & $\begin{array}{l}210 \\
7\end{array}$ & 4 & 4375 \\
\hline & $\begin{array}{l}17.00 \\
- \\
18.00\end{array}$ & $\begin{array}{l}201 \\
3\end{array}$ & $\begin{array}{l}25 \\
9\end{array}$ & $\begin{array}{l}222 \\
1\end{array}$ & 3 & 4496 \\
\hline
\end{tabular}

Sumber: Hasil survey, 2020

Tabel diatas adalah volume kendaraan pada lokasi penelitian di ruas jalan Raya Jakarta didepan pintu keluar Mall Of Serang, yang kemudian dijumlahkan pada tiap kelompok maupun total jumlah volume kendaraan.

\section{Analisis Penyeberang Jalan}

Dalam penelitian ini dihitung pada waktu interval 15 menit, waktu survey yang dilakukan yaitu pada pukul 07.00-08.00, 12.00-14.00, 17.00-18.00 pada hari jum'at, sabtu, minggu.

Tabel 4. Data Volume Penyeberangan Jalan

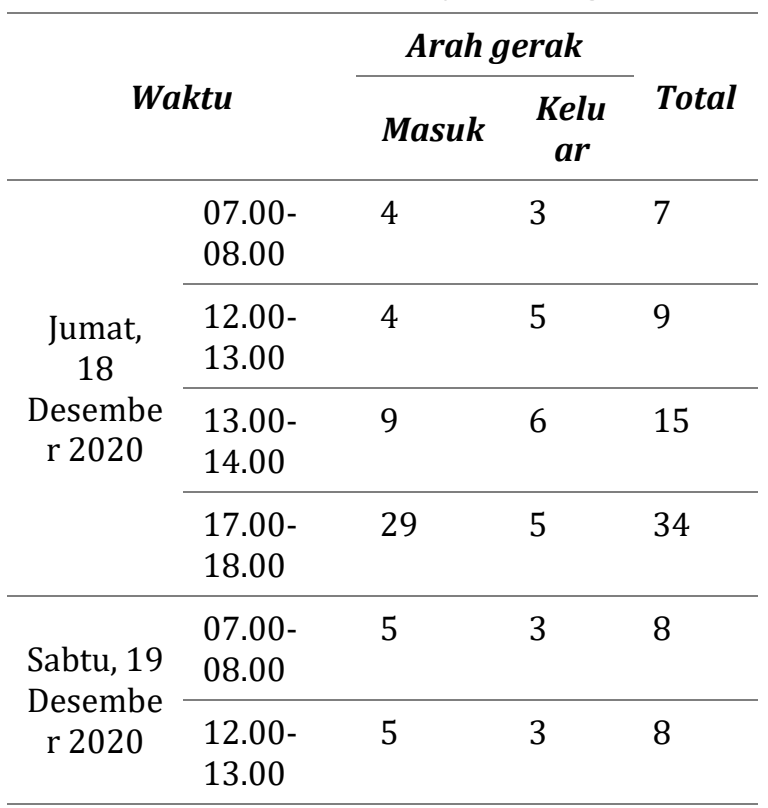




\begin{tabular}{|c|c|c|c|c|}
\hline \multirow{2}{*}{\multicolumn{2}{|c|}{ Waktu }} & \multicolumn{2}{|c|}{ Arah gerak } & \multirow[b]{2}{*}{ Total } \\
\hline & & Masuk & $\begin{array}{c}\text { Kelu } \\
\text { ar }\end{array}$ & \\
\hline & $\begin{array}{l}13.00- \\
14.00\end{array}$ & 18 & 10 & 28 \\
\hline & $\begin{array}{l}17.00- \\
18.00\end{array}$ & 11 & 4 & 15 \\
\hline \multirow{4}{*}{$\begin{array}{l}\text { Minggu, } \\
20 \\
\text { Desembe } \\
\text { r } 2020\end{array}$} & $\begin{array}{l}07.00- \\
08.00\end{array}$ & 9 & 4 & 13 \\
\hline & $\begin{array}{l}12.00- \\
13.00\end{array}$ & 3 & 3 & 6 \\
\hline & $\begin{array}{l}13.00- \\
14.00\end{array}$ & 7 & 11 & 18 \\
\hline & $\begin{array}{l}17.00- \\
18.00\end{array}$ & 7 & 8 & 15 \\
\hline
\end{tabular}

Sumber: Hasil survey, 2020

Berdasarkan Tabel diatas diketahui volume penyeberangan jalan terbesar pada hari jum'at pukul 17.00-18.00 sebesar 34 .

\section{Analisa kecepatan kendaraan}

Untuk menghitung faktor keamanan maka dilakukan juga survey kecepatan kendaraan yang melintas pada lokasi penelitian. Hasil penelitian kecepatan rata-rata kendaraan dapat dilihat pada tabel berikut ini:

Tabel 5. Data Kecepatan Rata-Rata Kendaraan

\begin{tabular}{|c|c|c|c|c|c|}
\hline \multirow[t]{2}{*}{ No } & \multirow[t]{2}{*}{ Jam } & \multicolumn{3}{|c|}{$\begin{array}{c}\text { Kecepatan } \\
(\mathrm{km} / \mathrm{jam})\end{array}$} & \multirow{2}{*}{$\begin{array}{c}\text { Kecepatan } \\
\text { rata-rata } \\
\text { tiap waktu }\end{array}$} \\
\hline & & $S M$ & $K R$ & $K S$ & \\
\hline 1 & \multirow{9}{*}{$\begin{array}{c}07.00 \\
- \\
08.00\end{array}$} & 28 & 25 & 22 & 25 \\
\hline 2 & & 27 & 26 & 22 & 25 \\
\hline 3 & & 26 & 28 & 20 & 24 \\
\hline 4 & & 28 & 26 & 23 & 26 \\
\hline 5 & & 26 & 27 & 23 & 25 \\
\hline 6 & & 27 & 25 & 23 & 25 \\
\hline 7 & & 27 & 23 & 24 & 25 \\
\hline 8 & & 26 & 24 & 20 & 23 \\
\hline 9 & & 26 & 25 & 23 & 24 \\
\hline
\end{tabular}

\begin{tabular}{|c|c|c|c|c|c|}
\hline \multirow[t]{2}{*}{ No } & \multirow[t]{2}{*}{ Jam } & \multicolumn{3}{|c|}{$\begin{array}{c}\text { Kecepatan } \\
(\mathrm{km} / \mathrm{jam})\end{array}$} & \multirow{2}{*}{$\begin{array}{c}\text { Kecepatan } \\
\text { rata-rata } \\
\text { tiap waktu }\end{array}$} \\
\hline & & $S M$ & $K R$ & $K S$ & \\
\hline 10 & \multirow{9}{*}{$\begin{array}{c}12.00 \\
- \\
13.00\end{array}$} & 25 & 23 & 29 & 26 \\
\hline 11 & & 23 & 22 & 33 & 26 \\
\hline 12 & & 21 & 22 & 22 & 22 \\
\hline 13 & & 20 & 21 & 24 & 22 \\
\hline 14 & & 25 & 21 & 20 & 22 \\
\hline 15 & & 23 & 22 & 29 & 25 \\
\hline 16 & & 23 & 21 & 33 & 26 \\
\hline 17 & & 20 & 23 & 22 & 21 \\
\hline 18 & & 23 & 23 & 34 & 26 \\
\hline 19 & \multirow{9}{*}{$\begin{array}{c}13.00 \\
- \\
14.00\end{array}$} & 21 & 19 & 24 & 21 \\
\hline 20 & & 22 & 23 & 28 & 24 \\
\hline 21 & & 20 & 5 & 25 & 17 \\
\hline 22 & & 24 & 5 & 31 & 20 \\
\hline 23 & & 23 & 21 & 24 & 22 \\
\hline 24 & & 22 & 21 & 19 & 21 \\
\hline 25 & & 23 & 21 & 24 & 23 \\
\hline 26 & & 23 & 21 & 22 & 22 \\
\hline 27 & & 23 & 20 & 23 & 22 \\
\hline 28 & \multirow{9}{*}{$\begin{array}{c}17.00 \\
- \\
18.00\end{array}$} & 25 & 23 & 29 & 26 \\
\hline 29 & & 24 & 22 & 25 & 24 \\
\hline 30 & & 25 & 21 & 33 & 26 \\
\hline 31 & & 25 & 23 & 29 & 25 \\
\hline 32 & & 25 & 19 & 27 & 23 \\
\hline 33 & & 22 & 18 & 21 & 20 \\
\hline 34 & & 20 & 19 & 34 & 24 \\
\hline 35 & & 25 & 22 & 29 & 25 \\
\hline 36 & & 22 & 33 & 26 & 27 \\
\hline \multicolumn{5}{|c|}{$\begin{array}{c}\text { Kecepatan rata-rata } \\
(\mathrm{km} / \mathrm{jam})\end{array}$} & 24 \\
\hline
\end{tabular}

Sumber: Hasil survey, 2020

Berdasarkan tabel diatas diketahui bahwa kecepatan rata-rata kendaraan yaitu 24 $\mathrm{km} / \mathrm{jam}$. Hasil kecepatan kendaraan yang telah dianalisa disesuaikan dengan metode 
$\mathrm{PV}^{2}$ dengan fasilitas penyeberangan yang telah disyaratkan.

\section{Analisa kecepatan penyeberangan}

Untuk mengetahui indikator perilaku penyeberangan maka perlu dilakukan juga survey kecepatan penyeberangan jalan di depan Mall of Serang. Hasil penelitian kecepatan rata-rata penyeberang jalan dapat dilihat pada tabel berikut ini:

Tabel 6. Data Kecepatan Penyeberangan

\begin{tabular}{|c|c|c|c|c|}
\hline \multirow{3}{*}{ No } & \multicolumn{4}{|c|}{$\begin{array}{c}\text { Kecepatan penyeberangan } \\
\text { (m/menit) }\end{array}$} \\
\hline & $\begin{array}{l}\text { Wanit } \\
\text { a }\end{array}$ & $\begin{array}{l}\text { Kecep } \\
\text { atan } \\
\text { rata- } \\
\text { rata }\end{array}$ & Pria & $\begin{array}{l}\text { Kecep } \\
\text { atan } \\
\text { rata- } \\
\text { rata }\end{array}$ \\
\hline & & $\begin{array}{l}\text { (m/me } \\
\text { nit) }\end{array}$ & & $\begin{array}{l}\text { (m/me } \\
\text { nit) }\end{array}$ \\
\hline 1 & 101.02 & \multirow{15}{*}{89.21} & 59.73 & \multirow{15}{*}{57.39} \\
\hline 2 & 117.68 & & 59.59 & \\
\hline 3 & 107.17 & & 59.15 & \\
\hline 4 & 78.81 & & 52.69 & \\
\hline 5 & 71.29 & & 54.4 & \\
\hline 6 & 95.19 & & 52.28 & \\
\hline 7 & 81.82 & & 52.62 & \\
\hline 8 & 103.39 & & 52.55 & \\
\hline 9 & 66.72 & & 61.16 & \\
\hline 10 & 88.49 & & 63.56 & \\
\hline 11 & 69.11 & & 57.94 & \\
\hline 12 & 92.74 & & 64.29 & \\
\hline 13 & 106.45 & & 52.55 & \\
\hline 14 & 81.48 & & 55.66 & \\
\hline 15 & 76.74 & & 62.61 & \\
\hline
\end{tabular}

Sumber: Hasil survey, 2020

Lokasi penelitian yaitu ruas jalan Raya Jakarta tepatnya didepan Mall of Serang merupakan jalan arteri primer dengan tipe empat lajur satu arah dan tidak ada median jalan. Lebar badan jalan sepanjang 13.2 meter untuk satu arah lalu lintas, kereb penghalang setinggi $30 \mathrm{~cm}$. Perkerasan jalan pada jalan ini menggunakan perkerasan asphalt.

\section{Analisa penentuan jenis fasilitas penyeberangan}

Data yang telah diperoleh dilapangan kemudian dianalisis dengan menggunakan metode $\mathrm{PV}^{2}$ dimana $\mathrm{P}$ adalah volume penyeberang jalan (orang/jam) dan $\mathrm{V}$ adalah volume arus lalu lintas (kend/jam) dari Perencanaan Teknis Fasilitas Pejalan Kaki 2018.

Tabel 7. Analisis Perhitungan Rata-Rata

\begin{tabular}{|c|c|c|c|c|}
\hline \multirow[b]{2}{*}{ No } & \multicolumn{4}{|c|}{$\begin{array}{c}\text { Kecepatan penyeberangan } \\
\text { (m/menit) }\end{array}$} \\
\hline & $\begin{array}{l}\text { Wanit } \\
\text { a }\end{array}$ & $\begin{array}{l}\text { Kecep } \\
\text { atan } \\
\text { rata- } \\
\text { rata } \\
\text { (m/me } \\
\text { nit) }\end{array}$ & Pria & $\begin{array}{l}\text { Kecep } \\
\text { atan } \\
\text { rata- } \\
\text { rata } \\
\text { (m/me } \\
\text { nit) }\end{array}$ \\
\hline 1 & 101.02 & \multirow{15}{*}{89.21} & 59.73 & \multirow{15}{*}{57.39} \\
\hline 2 & 117.68 & & 59.59 & \\
\hline 3 & 107.17 & & 59.15 & \\
\hline 4 & 78.81 & & 52.69 & \\
\hline 5 & 71.29 & & 54.4 & \\
\hline 6 & 95.19 & & 52.28 & \\
\hline 7 & 81.82 & & 52.62 & \\
\hline 8 & 103.39 & & 52.55 & \\
\hline 9 & 66.72 & & 61.16 & \\
\hline 10 & 88.49 & & 63.56 & \\
\hline 11 & 69.11 & & 57.94 & \\
\hline 12 & 92.74 & & 64.29 & \\
\hline 13 & 106.45 & & 52.55 & \\
\hline 14 & 81.48 & & 55.66 & \\
\hline 15 & 76.74 & & 62.61 & \\
\hline
\end{tabular}

Sumber: Hasil survey, 2020

Tabel diatas menunjukkan hasil perhitungan rata-rata volume penyeberang jalan dan volume arus lalu lintas selama tiga 
hari survey yang kemudian diolah menggunakan metode $\mathrm{PV}^{2}$.

Setelah mendapatkan nilai total volume penyeberangan jalan dan volume arus lalu lintas selama tiga hari maka hasil tersebut dirata-ratakan, sehingga didapat nilai ratarata volume penyeberang jalan sebesar 59 orang/jam dan volume arus lalu lintas sebesar 12597 kend/jam sehingga nilai $\mathrm{PV}^{2}$ sebesar $9303698748\left(9 \times 10^{9}\right)$.

Nilai $\mathrm{PV}^{2}$ yang didapat yaitu sebesar $9303698748\left(9 \times 10^{9}\right)$ lalu dimasukkan ke metode penentuan fasilitas penyeberangan pejalan kaki dari Perencanaan Teknis Fasilitas Pejalan Kaki 2018 (Tabel 1 dan Tabel 2), maka hasilnya sesuai dengan ( $>2 \mathrm{x}$ $10^{8}, \mathrm{P}=50-1100, \mathrm{~V}=>750$ ) dimana fasilitas penyeberangan yang dihasilkan yaitu pelican dengan lapak tunggu.

Berikut merupakan kriteria untuk fasilitas penyeberangan pelican cross :

1) Dipasang pada ruas jalan, minimal 300 meter dari persimpangan, atau

Pada jalan dengan kecepatan operasional rata-rata lalu lintas kendaraan $>40 \mathrm{~km} / \mathrm{jam}$.

\section{Desain fasilitas penyeberangan}

Desain fasilitas penyeberangan ini dibuat menggunakan software sketch up dan desain ini hanya mencakup desain gambar 3 dimensi, tidak termasuk beban-beban struktur.

Pada lokasi penelitian yang diteliti yaitu di pintu keluar Mall of Serang, ruas jalan tersebut mempunyai lalu lintas kendaran yang ramai, karena lokasinya yang dekat dengan exit tol Serang Timur. Didekat pintu keluar Mall of Serang, terdapat fasilitas penyeberangan berupa jembatan penyeberangan orang, jembatan penyeberangan orang ini dirasa kurang nyaman karna pada bagian tangga terdapat pelat yang berlubang dan ketika melakukan survey penyeberangan, penyeberang lebih sering menyeberang langsung dibandingkan menyeberang menggunakan jembatan penyeberangan orang.
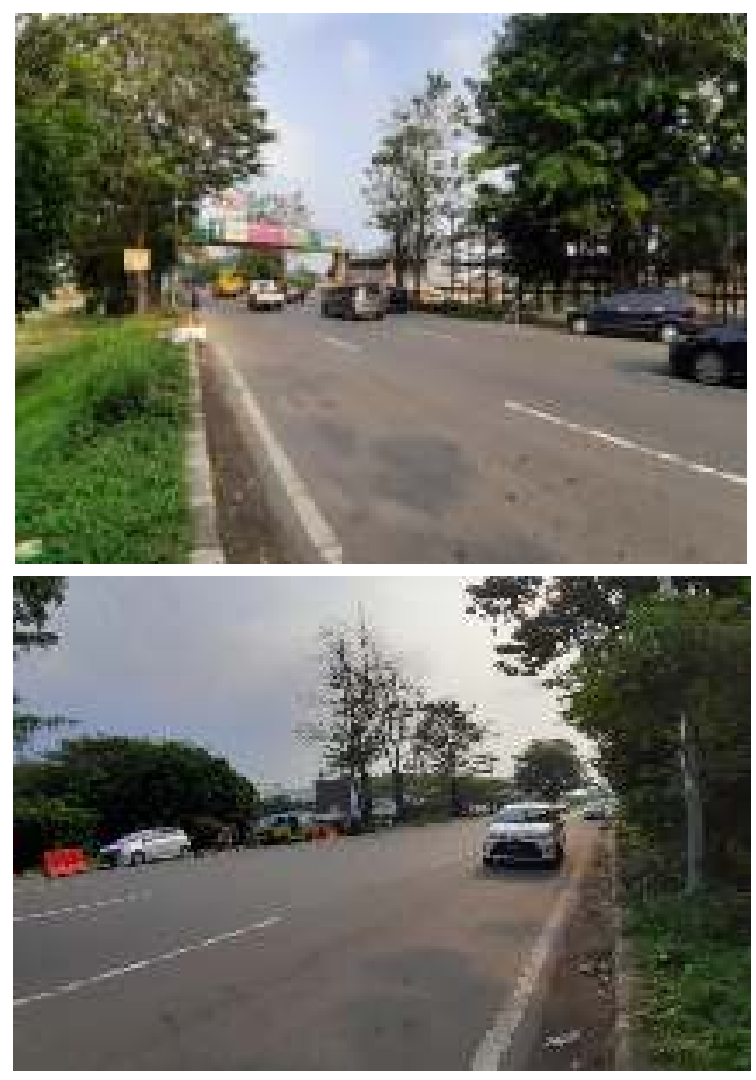

Gambar 1. Lokasi Survey

Sumber: Hasil survey, 2021

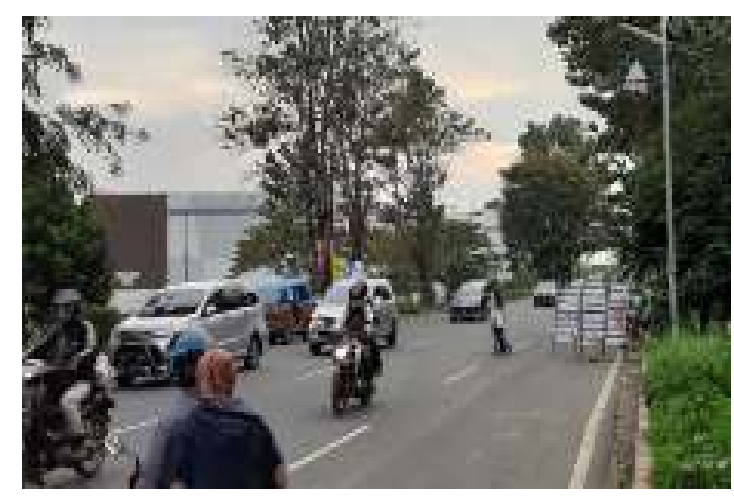

Gambar 2. Lokasi Survey

Sumber: Hasil survey, 2021

Pengguna jalan harus menunggu lama ketika hendak menyeberang, karena arus kendaraan yang melintas pada jalan tersebut melaju dengan kecepatan yang cukup tinggi, sehingga adanya kekhawatiran jika tiba-tiba ada kendaraan yang melaju cepat dan menghiraukan adanya penyeberang jalan. 


\section{Denah eksisting}

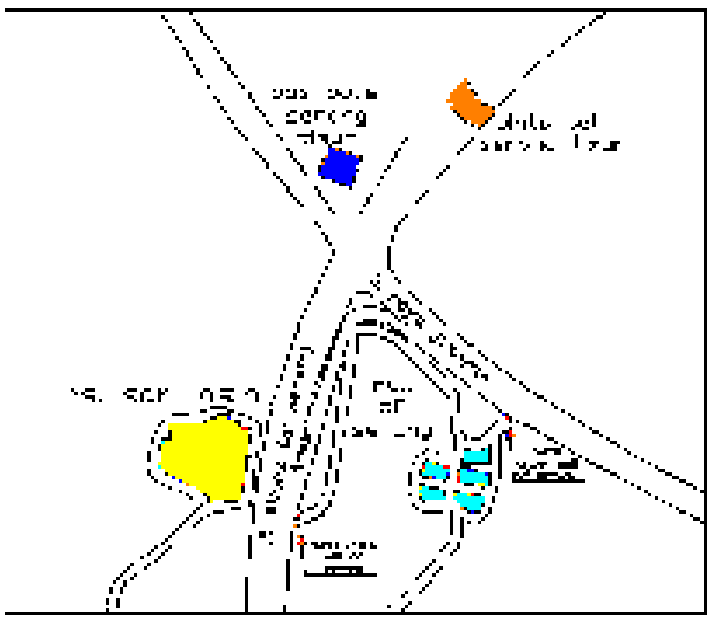

Gambar 3. Denah Eksisting Lokasi Penelitian

Sumber: Hasil survey, 2020

Gambar diatas merupakan denah eksisting pada lokasi penelitian yang telah dilaksanakan dan geometri jalan pada lokasi tersebut. Pada geometri jalan di depan Mall Of Serang terdapat jalan satu arah 4 lajur dengan lebar lajur 1 sebesar 3.5 meter, lajur 2 sebesar 3.1 meter, lajur 3 sebesar 3.3 meter, lajur 4 sebesar 3.3 meter dan tidak ada median.

\section{Desain pelican cross}

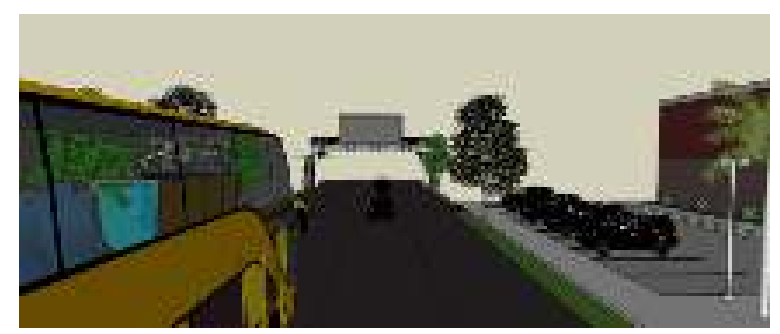

Gambar 4. Kondisi Eksisting Sebelum Dianalisis

Sumber: Hasil survey, 2021

Gambar diatas merupakan kondisi eksisting di pintu keluar mall of serang dengan fasilitas penyeberangan jembatan penyeberangan orang.

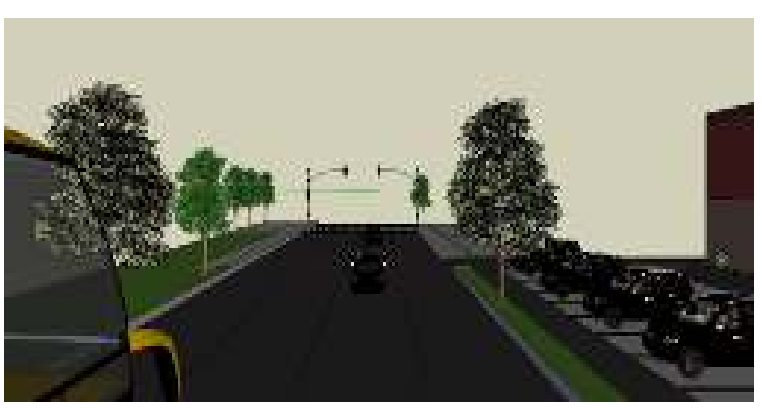

Gambar 5 Kondisi Eksisting Sesudah Dianalisis

Sumber: Hasil Desain, 2021

Gambar diatas merupakan kondisi eksisting di pintu keluar Mall of Serang dengan fasilitas penyeberangan pelican cross dengan lampu pengatur dan tidak dilengkapi lapak tunggu. Lapak tunggu dibuat jika sewaktu-waktu tidak sempat untuk melanjutkan menyeberang dikarnakan kehabisan waktu yang disediakan oleh lampu pengatur. Jalan didepan Mall of Serang tidak memungkinkan untuk penggunaan lapak tunggu karena tipe jalan yang satu arah dengan 4 lajur dan tidak ada median, jadi tidak ada kegiatan menyeberang lanjutan atau pergantian moda. Desain pelican cross ini dibuat berdasarkan Perencanaan Teknis Fasilitas Pejalan Kaki (2018) untuk menentukan jenis fasilitas penyeberangan orang.

\section{KESIMPULAN}

Hasil analisis data menunjukkan bahwa nilai rata-rata volume penyeberang jalan $(\mathrm{P})$ adalah sebesar 59 orang/jam, nilai rata-rata volume kendaraan (V) sebesar 12597 kend/jam dan nilai $\mathrm{PV}^{2}$ adalah sebesar $9303698748\left(9 \times 10^{9}\right)$. Angka inilah yang dijadikan dasar untuk menentukan fasilitas penyeberangan jalan. Sehingga dapat diperoleh bahwa pada ruas yang ditinjau tersebut, membutuhkan fasilitas penyeberangan orang berupa pelican cross.

1. Dibawah ini merupakan hasil desain pelican cross:

a. Panjang garis melintang: 2.50 meter 
b. Lebar garis melintang: 0.30 meter Traffic light: lampu pengatur penyeberang jalan dan lampu pengatur kendaraan berdasarkan Perencanaan Teknis Fasilitas Pejalan Kaki (2018) untuk menentukan jenis fasilitas penyeberangan orang.

\section{DAFTAR PUSTAKA}

[1] Budiman, A., Suryani, I., \& Wijianto, R. (2014). "Analisa Kebutuhan Fasilitas Penyeberangan Jalan Di Depan Kampus FT. Unirta Kota Cilegon". August.

[2] Idris, Zi. (2007). "Jembatan Penyeberangan Di Depan Kampus UMS Sebagai Fasilitas Pejalan Kaki". $7(1)$.

[3] Intari, D. E., Setiawati, D. N., \& Eliany, M. (2019). "Analisis Kebutuhan Fasilitas Penyeberangan Jalan Di Depan Universitas Sultan Ageng Tirtayasa Kota Serang". Jurnal Fondasi, 8(2).

[4] Juniardi. (2010). "Analisis Kebutuhan Faslitas Penyeberangan Perilaku Pejalan Kaki Menyeberang Di Ruas Jalan Kartini Bandar Lampung". Jurnal Teknik Sipil UBL, 1(1).

[5] Nunung Widyaningsih, Dr, D. I., \& Daniel, O. (2019). "Analisis Karakteristik dan Perlaku Penyeberangan Orang Pada Fasilitas Penyeberangan Zebra Cross dan Pelican Cross (Studi Kasus Ruas Jalan M. H. Thamrin)". Pengembangan Rekayasa Dan Teknologi, 15(1).

[6] PU, K. (2014). "Modul Ajar Kapasitas Jalan Perkotaan". In Panduan Kapasitas Jalan Indonesia. Direktorat Jendral Bina Marga.

[7] PUPR, K. (2018). "Perencanaan Teknis Fasilitas Pejalan Kaki”. Kementrian Pekerjaan Umum dan Perumahan Rakyat.

[8] Serang, B. P. S. K. (2020). "Serang Municipality in Figures 2020". BPS Kota Serang.
[9] Soehartono. (2013). “Analisis Sarana Penyeberangan dan Perilaku Pejalan Kaki Menyeberang Di Ruas Jalan Prof. Sudarto, SH Kecamatan Banyumanik Kota Semarang".

[10] Teknik, D. B. (1995). "Tata Cara Perencanaan Fasilitas Pejalan Kaki Di Kawasan Perkotaan". Departemen Pekerjaan Umum Direktorat Jenderal Bina Marga.

[11] UJM, J. F.-U. (2018). "Pedoman Penulisan Dan Penyusunan Tugas Akhir/Skripsi". Jurusan Teknik Sipil.

[12] Wowor, D. C., Lefrandt, L. I. R., \& Pandey, S. V. (2019). "Analisa Kebutuhan Fasilitas Penyeberangan Jalan Depan IT Center, Kota Manado". Jurnal Tekno, 17(73). 
